\title{
Literatur Review Terapi Pijat untuk Peningkatan Berat Badan pada Bayi Prematur dan atau Berat Badan Lahir Rendah (BBLR)
}

\author{
Dian Pratiwi \\ Politeknik Kesehatan Kementerian Kesehatan Manado / pratiwi.dian1826@gmail.com
}

\begin{abstract}
ABSTRAK
Latar Belakang: BBLR merupakan indikator kesehatan masyarakat yang berharga dari kesehatan ibu, gizi, pemberian layanan kesehatan, dan kemiskinan karena bayi BBLR berada pada risiko kematian danpenyakit segera setelah lahir dan penyakit tidak menular dalam perjalanan hidup. BBLR dianggap sebagai masalah kesehatan masyarakat yang signifikan karena diperkirakan 15\% sampai 20\%dari semua kelahiran di seluruh dunia adalah BBLR.

Tujuan: untuk menganalisis literatur yang berkaitan dengan terapi pijat pada bayi premature dan atau BBLR.

Metode: Metode yang digunakan dalam mencari artikel adalah literature review dengan menggunakan database google scholar.

Hasil: Sebanyak 2740 artikel diindentifikasi dari database dan 5 artikel dari pencarian manual. Setelah proses screening meninggalkan 13 artikel yang dapat dinilai kelayakannya. Lima dari 13 artikel dikeluarkan dengan alasan, menyisakan 8 artikel untuk dimasukkan.

Kesimpulan: Terapi pijat memiliki dampak positif terhadap peningkatan berat badan bayi BBLR dan bayi prematur.
\end{abstract}

Kata Kunci : Terapi Pijat, Bayi Berat Lahir Rendah, Bayi Prematur

\begin{abstract}
Background: LBW is a valuable public health indicator of maternal health, nutrition, health service delivery, and poverty because LBW babies are at risk of death and disease immediately after birth and noncommunicable diseases in the course of life. LBW is considered a significant public health problem because it is estimated that $15 \%$ to $20 \%$ of all births worldwide are LBW.

Objective: to analyze the literature related to massage therapy in premature and or low birth weight infants. Methods: The method used in searching for articles is a literature review using the Google Scholar database. Results: A total of 2740 articles were identified from the database and 5 articles from manual searches. After the screening process, 13 articles were left that could be assessed for eligibility. Five of the 13 articles were excluded on grounds, leaving 8 articles for inclusion.

Conclusion: Massage therapy has a positive impact on increasing the weight of LBW babies and premature babies.
\end{abstract}

Keywords: Massage Therapy, Low Birth Weight Babies, Premature Babies

\section{PENDAHULUAN}

World Health Organization (WHO) mendefinisikan berat badan lahir rendah (BBLR) sebagai berat lahir kurang dari 2500 gram terlepas dari usia kehamilan. BBLR merupakan indikator kesehatan masyarakat yang berharga dari kesehatan ibu, gizi, pemberian layanan kesehatan, dan kemiskinan karena bayi
BBLR berada pada risiko kematian dan penyakit segera setelah lahir dan penyakit tidak menular dalam perjalanan hidup. (1) - Lebih dari $80 \%$ dari 2,5 juta bayi di dunia yang meninggal setiap tahun adalah BBLR, dan sebagian besar telah dilaporkan dari negara-negara berpenghasilan rendah dan menengah termasuk Indonesia. 
Bayi BBLR 20 kali lebih mungkin mengalami komplikasi dan meninggal dibandingkan dengan bayi dengan berat badan normal. Bayi BBLR memiliki potensi risiko defisit kognitif, keterlambatan motorik, cerebral palsy, masalah perilaku, psikologis dan juga memiliki efek jangka panjang terjadi risiko penyakit kardiovaskular, paru-paru dan metabolisme. Selain itu, BBLR juga beresiko mengalami obesitas, diabetes, hipertensi dan penyakit ginjal di kemudian hari. $(1,2)$

BBLR dianggap sebagai masalah kesehatan masyarakat yang signifikan karena diperkirakan $15 \%$ sampai $20 \%$ dari semua kelahiran di seluruh dunia adalah BBLR. (1) Sembilan puluh persen kasus BBLR terjadi di negara berkembang termasuk Indonesia. Dengan kata lain, ada 1 dari 7 bayi lahir dengan berat badan lahir rendah di dunia. Negara Indonesia merupakan peringkat kesembilan di dunia dengan kasus bayi BBLR mencapai 15,5\%. (3)

Bayi lahir dengan berat badan 20002500 gram lebih mungkin untuk mengalami kematian neonatal empat kali lebih besar dari bayi dengan berat 2500-3000 gram, dan sepuluh kali lebih rentan terhadap penyakit daripada bayi yang lahir dengan berat 3000-3500 gram. ${ }^{\text {(3) }}$

Bayi BBLR dan prematur membutuhkan tindakan terapi suportif karena masalah fisik, mental, dan psikologis mereka. Bayi BBLR dan prematur yang bertahan hidup beresiko tinggi cacat fisik dan mengalami komplikasi dibandingkan dengan bayi cukup bulan. Kondisi bayi tersebut dapat berdampak pada kondisi ibu. Ibu akan mengalami stress yang diekspresikan oleh rasa takut, gelisah, menangis, cemas, depresi, mudah tersinggung, dan kecewa. (4) Penelitian Malakouti et al., tahun 2013 menunjukkan bahwa hanya $16,82 \%$ yang memiliki keterampilan dalam merawat bayi prematur salah satunya adalah pijat bayi. ${ }^{(5)}$ Keterlibatan orang tua dalam merawat bayi prematur yang dirawat di rumah sakit dapat memfasilitasi perkembangan neonates, membantu pemulangan dini dari rumah sakit dan membantu mengurangi lama rawat inap dan biaya di rumah sakit. (4)

Salah satu tindakan suport yang dapat diberikan ibu untuk bayi BBLR dan prematur adalah denga menggunakan teknik stimulasi sensorik. Berbagai bentuk stimulasi sensorik meliputi pijat, kontak kulit ke kulit, sentuhan lembut (dan gosokan), dan suara. (6) Di negara maju, penggunaan pengobatan komplementer dan stimulasi bayi meningkat, dan pijat dianggap sebagai tindakan suportif komplementer untuk bayi di NICU. Pijat yang dilakukan sendiri oleh ibu memiliki manfaat yaitu mengurangi biaya dibandingkan dengan pijat yang dilakukan oleh tenaga kesehatan. Selain itu, pengobatan komplementer tidak hanya ekonomis, tetapi juga tidak memiliki efek samping yang serius, reaksi obat, dan mudah dilakukan dan diterima oleh pasien. (4) Beberapa penelitian menekankan manfaat terapi pijat. Terapi pijat dapat meningkatkan kontak fisik antara ibu dan bayi, dapat mempercepat pertumbuhan dan perkembangan fisik dan mental bayi BBLR dan premature. ${ }^{(\mathbf{7 , 8})}$

Namun demikian sentuhan yang berlebihan selama kegiatan sehari-hari seperti 
menyusui, pemeriksaan dan penggantian popok dikaitkan dengan kejadian hipokisa. Penjelasan yang mungkin tentang efek dari kedua jenis sentuhan ini adalah bahwa pijatan adalah sentuhan lembut dan menenangkan bagi bayi premature anak, sedangkan sentuhan yang berhubungan dengan prosedur rutin sering. Selain itu, pijat diterapkan sekali atau dua kali sehari, sementara sentuhan medis dan perawat terjadi terus menerus sepanjang hari dan membuat tidak nyaman dan/atau menyakitkan. (9)

Tujuan dari penelitian ini adalah untuk melakukan tinjauan sistematis untuk mengidentifikasi, meringkas penelitian, dan untuk menilai manfaat pemberian terapi pijat, dibandingkan dengan perawatan standar pada BBL yang dirawat di rumah sakit

\section{METODE}

Metode dikembangkan sesuai dengan panduan Preferred Reporting Items for Systematic Reviews and Meta- Analyses (PRISMA).

\section{Kriteria inklusi dan eksklusi}

Tidak ada batasan jenis penelitian. Penelitian tersebut berkaitan dengan Bayi BBLR dan baby massage dan penelitian sudah dipublikasikan dalam bahasa Inggris. Waktu publikasi antara tahun 2020-2021. Kutipan tanpa abstrak dan/atau teks lengkap, laporan anonim, editorial, dan buku dikeluarkan dari analisis. Kemudian, penelitian dievaluasi berdasarkan proses 4 tahap PRISMA yang terdiri dari identifikasi artikel, penyaringan, penilaian kriteria untuk menerima artikel, dan terakhir penilaian artikel.

\section{Strategi pencarian}

Pencarian dilakukan antara tahun 2020 sampai 2021. Database yang digunakan adalah google scholar. Istilah dalam pencarian meliputi "preterm infant", "low birth weight infant", "baby massage", "infant massage", "usual care”, "weight gain", "hospitalization" dan "developmental delay". Kata yang serupa digabung menggunakan operator "OR" sementara "AND" digunakan untuk menggabungkan antar kata kunci. Sebagai contoh strategi pencarian yang digunakan di google scholar adalah sebagai berikut preterm infant OR low birth weight infant AND baby massage OR infant massage AND usual care AND weight gain OR hospitalization OR developmental delay.

\section{HASIL}

Sebanyak 2740 artikel diindentifikasi dari database dan 5 artikel dari pencarian manual. Tercatat ada 2745 artikel setelah proses screening duplikat. Pada tahap penyaringan judul dan abstrak, 2620 artikel dikeluarkan karea tidak relevan dengan topik pencarian, dan meninggalkan 125 artikel. Seratus dua puluh lima artikel dinilai kelayakannya untuk teks lengkap dan meninggalkan 13 artikel. Lima dari 13 artikel dikeluarkan dengan alasan, menyisakan 8 artikel untuk dimasukkan. Proses untuk identifikasi, penyaringan kelayakan dan inklusi, yang mendasari pencarian sistematis ini, diilustrasikan oleh diagram alir PRISMA. 


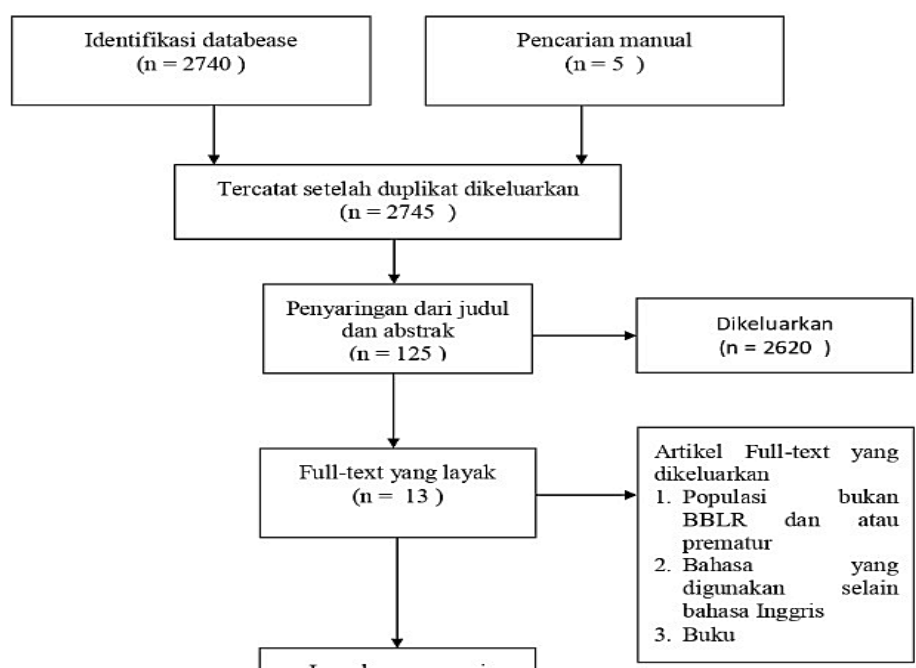

rnal yang sesu

Gambar 1. Diagram alir proses seleksi artikel

Tabel 1. Terapi pijat pada Bayi Berat Badan Lahir Rendah (BBLR)

\begin{tabular}{|c|c|c|c|c|c|c|c|}
\hline No & Judul & Penulis & Tahun & Metode & Sampel & Intervensi & Hasil \\
\hline 1. & $\begin{array}{l}\text { Effects of the } \\
\text { Mother's } \\
\text { Individual } \\
\text { Stimulation on the } \\
\text { Growth and } \\
\text { Development } \\
\text { of Infants With L } \\
\text { ow Birth } \\
\text { Weight History }\end{array}$ & $\begin{array}{l}\text { Linda Meliati, } \\
\mathrm{Ni} \text { Putu } \\
\text { Karunia } \\
\text { Ekayani dan } \\
\text { Siti Khadijah }\end{array}$ & 2020 & $\begin{array}{l}\text { Penelitian } \\
\text { Quasi } \\
\text { Eksperiment } \\
\text { dengan } \\
\text { rancangan } \\
\text { nonrandomiz } \\
\text { ed pretest- } \\
\text { posttest } \\
\text { design }\end{array}$ & $\begin{array}{l}\text { ibu dan } \\
\text { bayinya } \\
\text { yang } \\
\text { berusia 0- } \\
12 \text { bulan } \\
\text { dengan } \\
\text { riwayat } \\
\text { Berat } \\
\text { Badan } \\
\text { Lahir } \\
\text { Rendah } \\
\text { (BBLR) }\end{array}$ & Terapi pijat & $\begin{array}{l}\text { Skor tumbuh } \\
\text { kembang bayi } \\
\text { BBLR } \\
\text { meningkat } \\
\text { setelah } \\
\text { mendapat } \\
\text { stimulasi } \\
\text { mandiri dari } \\
\text { ibunya }\end{array}$ \\
\hline 2. & $\begin{array}{l}\text { The effectiveness } \\
\text { of baby massage } \\
\text { in increasing } \\
\text { infant's body } \\
\text { weight }\end{array}$ & $\begin{array}{l}\text { Kurniati Puji } \\
\text { Lestari, Firdha } \\
\text { Rahma } \\
\text { Nurbadlina, } \\
\text { Wagiyo, } \\
\text { Muhammad } \\
\text { Jauhar }\end{array}$ & 2020 & $\begin{array}{l}\text { quasi- } \\
\text { experimental } \\
\text { pre and post- } \\
\text { test type with } \\
\text { control } \\
\text { group }\end{array}$ & $\begin{array}{l}\text { bayi } \\
\text { dengan } \\
\text { riwayat } \\
\text { BBLR }\end{array}$ & Terapi pijat & $\begin{array}{l}\text { Ada pengaruh } \\
\text { pijat bayi } \\
\text { terhadap } \\
\text { peningkatan } \\
\text { berat badan } \\
\text { bayi dengan } \\
\text { riwayat } \\
\text { BBLR secara } \\
\text { signifikan } \\
\text { dengan p } \\
\text { value }<0,05\end{array}$ \\
\hline 3. & $\begin{array}{l}\text { Massage therapy } \\
\text { for weight gain in } \\
\text { preterm neonates: } \\
\text { A systematic } \\
\text { review and meta- } \\
\text { analysis of } \\
\text { randomized } \\
\text { controlled trials }\end{array}$ & $\begin{array}{l}\text { Li-Chin Lu, } \\
\text { Shao-Huan } \\
\text { Lan, Yen-Ping } \\
\text { Hsieh, Long } \\
\text { Yau Lin, Jong- } \\
\text { Chen Chen, } \\
\text { Shou-Jen Lan }\end{array}$ & 2020 & $\begin{array}{l}\text { systematic } \\
\text { review dan } \\
\text { meta- } \\
\text { analysis }\end{array}$ & $\begin{array}{l}\text { Bayi } \\
\text { premature } \\
\text { dengan } \\
\text { BBLR }\end{array}$ & Terapi pijat & $\begin{array}{l}\text { Terapi pijat } \\
\text { bermanfaat } \\
\text { untuk } \\
\text { peningkatan } \\
\text { berat badan } \\
\text { bayi prematur }\end{array}$ \\
\hline
\end{tabular}




\begin{tabular}{|c|c|c|c|c|c|c|c|}
\hline No & Judul & Penulis & Tahun & Metode & Sampel & Intervensi & Hasil \\
\hline 4. & $\begin{array}{l}\text { Effectiveness of } \\
\text { the application of } \\
\text { massage therapy } \\
\text { and kinesitherapy } \\
\text { by parents on } \\
\text { premature } \\
\text { neonates: A } \\
\text { research protocol }\end{array}$ & $\begin{array}{l}\text { María José } \\
\text { Álvarez- } \\
\text { Álvarez, } \\
\text { Daniel } \\
\text { Fernández- } \\
\text { García, Juan } \\
\text { Gómez- } \\
\text { Salgado, } \\
\text { Beatriz Ordás, } \\
\text { María Dolores } \\
\text { Rodríguez- } \\
\text { González, San } \\
\text { tiago } \\
\text { Martínez- } \\
\text { Isasi }\end{array}$ & 2019 & $\begin{array}{l}\text { A quasi- } \\
\text { experimental } \\
\text { community } \\
\text { intervention } \\
\text { trial }\end{array}$ & $\begin{array}{l}\text { Bayi } \\
\text { prematur }\end{array}$ & Terapi pijat & $\begin{array}{l}\text { Terapi pijat } \\
\text { dan protokol } \\
\text { kinesiterapi } \\
\text { efektif dalam } \\
\text { mendorong } \\
\text { pertumbuhan } \\
\text { dan perkembanga } \\
\text { n bayi } \\
\text { prematur }\end{array}$ \\
\hline 5. & $\begin{array}{l}\text { The Effects of } \\
\text { Massage on the } \\
\text { Weight Gain of } \\
\text { Preterm Infants: A } \\
\text { Systematic } \\
\text { Review }\end{array}$ & $\begin{array}{l}\text { Serap } \\
\text { Ozdemir, } \\
\text { Suzan Yildiz }\end{array}$ & 2019 & $\begin{array}{l}\text { Systematic } \\
\text { Review }\end{array}$ & $\begin{array}{l}\text { Bayi } \\
\text { Prematur }\end{array}$ & Terapi pijat & $\begin{array}{l}\text { Terapi pijat } \\
\text { dapat } \\
\text { meningkatka } \\
\mathrm{n} \text { berat badan } \\
\text { pada bayi } \\
\text { prematur }\end{array}$ \\
\hline 6. & $\begin{array}{l}\text { The Effects of } \\
\text { Massage Therapy } \\
\text { with or without } \\
\text { Physical Exercises } \\
\text { on the Weight of } \\
\text { Premature Infants } \\
\text { Admitted to the } \\
\text { Neonatal } \\
\text { Intensive Care } \\
\text { Unit: } \\
\text { Randomized } \\
\text { Clinical Trial }\end{array}$ & $\begin{array}{l}\text { Sedighe } \\
\text { Montaseri, } \\
\text { Rokhsareh } \\
\text { Barati, Mitra } \\
\text { Edraki, ariba } \\
\text { Hemmati }\end{array}$ & 2019 & $\begin{array}{l}\text { Randomized } \\
\text { Clinical Trial }\end{array}$ & $\begin{array}{l}\text { Bayi } \\
\text { BBLR }\end{array}$ & $\begin{array}{l}\text { Pijat, Pijat } \\
\text { dengan } \\
\text { latihan fisik } \\
\text { dan tanpa } \\
\text { intervensi } \\
\text { apapun }\end{array}$ & $\begin{array}{l}\text { Pijat dengan } \\
\text { atau tanpa } \\
\text { latihan dapat } \\
\text { menyebabkan } \\
\text { kenaikan } \\
\text { berat badan } \\
\text { pada bayi } \\
\text { BBLR }\end{array}$ \\
\hline 7. & $\begin{array}{lr}\text { Effectiveness of } \\
\text { Massage } & \text { Therapy } \\
\text { For } & \text { Preterm } \\
\text { Infants: } & \text { A } \\
\text { Literature } & \text { Review }\end{array}$ & $\begin{array}{l}\text { Lia Dian } \\
\text { Ayuningrum }\end{array}$ & 2017 & $\begin{array}{l}\text { Literature } \\
\text { Review }\end{array}$ & $\begin{array}{l}\text { Bayi } \\
\text { prematur }\end{array}$ & Terapi pijat & $\begin{array}{l}\text { Terapi piat } \\
\text { dapat } \\
\text { memberikan } \\
\text { kenyamanan } \\
\text { dan } \\
\text { meningkatka } \\
\text { n } \\
\text { pertumbuhan } \\
\text { fisik, kualitas } \\
\text { tidur }\end{array}$ \\
\hline 8. & $\begin{array}{ll}\text { The Effect } & \text { of } \\
\text { Massage } & \text { on } \\
\text { Weight Gain } & \text { of } \\
\text { Low-Weight } & \\
\text { Hospitalized } & \\
\text { Infants: } & \text { A } \\
\text { Randomized } & \\
\text { Clinical Trial } & \end{array}$ & $\begin{array}{l}\text { Sahar Johari, } \\
\text { Hojjat Allah } \\
\text { Haghgou , } \\
\text { Mostafa } \\
\text { Daemi } \\
\text { Tahereh } \\
\text { Rezaeiyan, } \\
\text { Zahra Mosala } \\
\text { Nejad }\end{array}$ & 2016 & $\begin{array}{l}\text { Randomized } \\
\text { Clinical Trial }\end{array}$ & $\begin{array}{l}\text { Bayi } \\
\text { BBLR }\end{array}$ & Terapi pijat & $\begin{array}{l}\text { Pijat melalui } \\
\text { stimulasi } \\
\text { taktil-kinetik } \\
\text { menghasilkan } \\
\text { penambahan } \\
\text { berat badan } \\
\text { pada } \\
\text { neonatus } \\
\text { BBLR. }\end{array}$ \\
\hline
\end{tabular}




\section{PEMBAHASAN}

Seiring dengan tinjauan ini, penelitian yang berkaitan dengan terapi pijat dan penambahan berat badan diperiksa. Dalam konteks ini, ada 8 dokumen yang relevan dan selanjutnya dianalisis. Studi literature menunjukkan hasil bahwa durasi terapi pijat biasanya dilakukan sekitar 15-20 menit pada pagi dan sore hari setelah menyusui. Pengukuran hasil dinilai berdasarkan peningkatan panjang badan, lingkar kepala, berat badan, dan perkembangannya setelah diberikan intervensi selama 30 hari. (10,11) Namun demikian ada intervensi pijatan yang dilakukan dengan durasi 10-15 menit, dan waktunya 3-4 kali sehari. Pengukuran hasil terapi pijat dinilai pada hari ke 7 , hari ke 14 , satu bulan dan dua minggu.

Hasil studi literartur menunjukkan bahwa terapi pijat secara signifikan meningkatkan kenaikan berat badan harian pada bayi prematur, termasuk bayi dengan

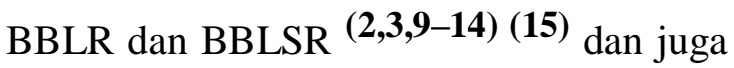
meningkatkan fungsi kardiopulmoner. (16) Terapi pijat dapat mengurangi stress, sekresi kortisol dan meningkatkan sekresi hormon melatonin pada bayi baru lahir. Peningkatan kadar hormon melatonin membuat bayi merasa lebih baik sehingga memperbaiki pola tidur dan meningkatkan berat badannya. (11)(15) Rata-rata peningkatan berat badan pada bayi dengan berat badan lahir rendah sebesar 7,96 g/hari dan untuk berat badan lahir sangat rendah sebesar 2,94 g/hari. Terapi pijat juga memiliki manfaat lain yaitu dapat memperbaiki tanda-tanda vital dan memiliki efek positif pada perkembangan saraf. (17,18) Terapi pijat dapat dilakukan oleh tenaga kesehatan maupun ibu. ${ }^{(9)}$

Manfaat terapi pijat selain yang disebutkan diatas, terapi pijat juga dapat meningkatkan aktivitas vagal, motilitas lambung, insulin, dan IGF-1 pada pada bayi prematur. Pijat juga dapat membantu melepaskan motilin dan gastrin, yang berfungsi untuk meningkatkan peristaltik dan buang air besar. Rangsangan taktil juga dapat meningkatkan ornitin dekarboksilase dan enzim penting yang terlibat dalam sintesis protein yang berkontribusi untuk penambahan berat badan. (13) Manfaat terapi pijat dari segi ekonomi yaitu bahwa terapi pijat dapat mengurangi masa inap bayi di rumah sakit sehingga akan menurunkan biaya perawatan. ${ }^{(12)}$

Langkah-langkah terapi pijat yaitu ibu mencuci tangan dan menghangatkannya dengan cara menggosok kedua tangan. Kemudian, bayi dibaringkan tengkurap, hanya memakai popok, dan ibu memijatnya dari kepala sampai kaki dalam 3 fase, masing-masing fase berlangsung selama 5 menit. Selama fase pertama, bayi dipijat dengan tekanan ringan menggunakan bagian jari kedua tangan yang halus dan lembut. Pada fase dasar ini, masing-masing dari 5 area berikut dipijat selama 1 menit:

1) 12 gerakan pijatan ( 5 detik per gerakan) dari kepala ke bawah di kedua sisi wajah hingga leher dan sebaliknya;

2) 12 gerakan pijat (5 detik per gerakan) dari belakang leher sampai ke bahu dan sebaliknya;

3) 12 gerakan pijat (5 detik per gerakan) dari bagian atas punggung sampai ke pinggang dan sebaliknya; 
4) 12 gerakan pijat (5 detik per gerakan) dari paha ke pergelangan kaki dan sebaliknya; dan

5) 12 gerakan pijat (5 detik per gerakan) dari bahu ke pergelangan tangan dan sebaliknya. (4)

Fase kedua, bayi dibaringkan terlentang, dan masing-masing dari 5 area berikut dipijat selama 1 menit:

1) 12 gerakan pijat (5 detik per gerakan) menyentuh wajah dan pipi;

2) 12 gerakan pijat (5 detik per gerakan) menyentuh dada;

3) 12 gerakan pijat (5 detik per gerakan) menyentuh perut;

4) 12 gerakan pijat (5 detik per gerakan) menyentuh telapak tangan; dan

5) 12 gerakan pijat (5 detik per gerakan) menyentuh telapak kaki. Fase terakhir, bayi dibaringkan terlentang, dan 6 gerakan ekstensi dan fleksi (1 setiap 10 detik) diterapkan pada 6 area (bahu, siku, lutut, pergelangan tangan, tangan, dan kaki). Langkah-langkah tersebut dapat dilihat pada gambar 2. (4)

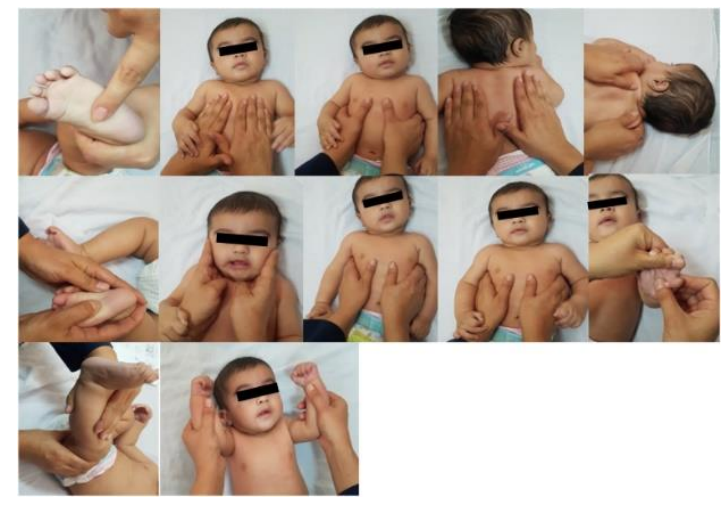

Gambar 2. Pijat bayi oleh ibu

Sumber: Lotfalipour et al., (2019)

Untuk membedakan pengaruh tekanan pijat, ada satu artikel yang mengklasifikasikan pijat menjadi dua kelompok yaitu tekanan ringan (sentuhan, rangsangan taktil dan pijat palsu) dan tekanan sedang (pijat). Bayi prematur yang menerima tekanan sedang mengalami kenaikan berat badan lebih banyak setiap hari daripada bayi prematur yang menerima pijatan palsu atau sentuhan (p 0,004).

Beberapa artikel membahas terkait posisi pijat bayi. Posisi tengkurap dapat meningkatkan detak jantung bayi. Namun sebaliknya penelitian Ma et al, dalam Elsagh et al tahun 2019 menyatakan bahwa posisi tengkurap dapat mengurangi curah jantung. (16) Penelitian Alinejad tahun 2014 menyatakan bahwa posisi tengkurap berdampak positif terhadap ventilasi dan kapasitas paru-paru lebih baik. (20) Penelitian Oshi et al tahun 2018 menyebutkan bahwa keuntungan dari posisi tengkurap adalah paru-paru akan berfungsi dengan baik dan meningkatkan $\mathrm{SaO}^{2}$.

Saturasi $\mathrm{O}_{2}$ pada posisi tengkurap lebih tinggi dibandingkan pada posisi terlentang. (16)

Selain pemberian terapi pijat, pemberian ASI juga dapat meningkatkan pertambahan berat badan bayi premature dan BBLR. Pemberian ASI mendorong pertumbuhan jaringan karena pemanfaatan nutrisi yang optimal dari ASI. Protein bioaktif yang ada dalam ASI merupakan faktor yang berkontribusi dalam meningkatkan penyerapan dan penggunaan nutrisi dan meningkatkan pertumbuhan bayi. Akibatnya, pemberian ASI sampai mereka mencapai kondisi klinis yang stabil dapat meningkatkan deposisi massa bebas lemak pada bayi. ${ }^{(22)}$ 


\section{KESIMPULAN}

Terapi pijat memiliki dampak positif terhadap peningkatan berat badan bayi BBLR dan bayi premature. Selain itu terapi pijat memiliki manfaat dapat meningkatkan mobilitas lambung, membantu melepaskan motilin dan gastrin dan dari segi ekonomi dapat mengurangi masa inap bayi di rumah sakit.

\section{SARAN}

Pemberian terapi pijat bayi dapat dioptimalkan dengan mengembangkan menjadi prosedur perawatan bayi BBLR dan prematur di rumah sakit dan dilanjutkan di rumah.

\section{DAFTAR PUSTAKA}

1. Anil KC, Basel PL, Singh S. Low birth weight and its associated risk factors: Health facilitybased case-control study. PLoS One [Internet]. 2020;15(6 June):1-10. Available from: http://dx.doi.org/10.1371/journal.pone.0234907

2. Gete DG, Waller M, Mishra GD. Effects of maternal diets on preterm birth and low birth weight: A systematic review. Br J Nutr. 2020;123(4):446-61.

3. Lestari KP, Nurbadlina FR, Wagiyo, Jauhar M. The effectiveness of baby massage in increasing infant's body weight. J Public health Res. 2021;10(s1):233.

4. Lotfalipour B, Tirgari B, Pouraboli B, Mirzaee M. Effect of preterm infant massage by the mother on the mood of mothers having preterm infants. J Chiropr Med [Internet]. 2019;18(1):67-76. Available from: https://doi.org/10.1016/j.jcm.2018.11.001

5. Malakouti J, Jabraeeli M, Valizadeh S, Babapour J, Study P. Mother's Experience of Having a Preterm Infant in the Neonatal Intensive Care Unit, a Phenomenological Study. 2013;5(4):17281.

6. Aita M, Stremler R, Feeley N, Lavallée A, De Clifford-Faugère G. Effectiveness of interventions during NICU hospitalization on the neurodevelopment of preterm infants: A systematic review protocol. Syst Rev. 2017;6(1):1-5.

7. Arzani A, Valizadeh L, Zamanzadeh V, Mohammadi E. Mothers' strategies in handling the prematurely born infant: a qualitative study. J Caring Sci. 2015;4(1):13-24.

8. Niemi A-K. Review of Randomized Controlled Trials of Massage in Preterm Infants. Children. 2017;4(4):21.

9. Álvarez MJ, Fernández D, Gómez-Salgado J, Rodríguez-González D, Rosón M, Lapeña S. The effects of massage therapy in hospitalized preterm neonates: A systematic review. Int J Nurs Stud [Internet]. 2017;69:119-36. Available from: http://dx.doi.org/10.1016/j.ijnurstu.2017.02.009

10. Meliati L, Karunia Ekayani NP, Khadijah S. Effects of the Mother's Individual Stimulation on the Growth and Development of Infants With Low Birth Weight History. J Holist Nurs Midwifery. 2020;30(4):200-7.

11. Montaseri S, Barati R, Edraki M, Hemmati F. The effects of massage therapy with or without physical exercises on the weight of premature infants admitted to the neonatal intensive care unit: A randomized clinical trial. Shiraz E Med J. 2020;21(2):0-5.

12. Lu LC, Lan SH, Hsieh YP, Lin LY, Chen JC, Lan SJ. Massage therapy for weight gain in preterm neonates: A systematic review and meta-analysis of randomized controlled trials. Complement Ther Clin Pract [Internet]. 2020;39(500):101168. Available from: https://doi.org/10.1016/j.ctcp.2020.101168

13. Özdemir S, Yildiz S. The Effects of Massage on theWeight Gain of Preterm Infants: A Systematic Review. J Tradit Med Complement Ther. 2019;2(1):33-41.

14. Johari S, Haghgou H, Daemi M, Rezaeiyan T, Mosala Nejad Z. The Effect of Massage on Weight Gain of Low-Weight Hospitalized Infants: A Randomized Clinical Trial. Phys Treat 
Specif Phys Ther. 2016;5(4):205-10.

15. Hymel GM, Rich GJ. Health psychology as a context for massage therapy: a conceptual model with CAM as mediator. J Bodyw Mov Ther. 2014 Apr;18(2):174-82.

16. Elsagh A, Lotfi R, Amiri S, Gooya HH. Comparison of Massage and Prone Position on Heart Rate and Blood Oxygen Saturation Level in Preterm Neonates Hospitalized in Neonatal Intensive Care Unit: A Randomized Controlled Trial. Iran J Nurs Midwifery Res. 2019;24(5):343-7.

17. Oren-Amit A, Berkovitch M, Bahat H, Goldman M, Kozer E, Ziv-Baran T, et al. Complementary and alternative medicine among hospitalized pediatric patients. Complement Ther Med. 2017 Apr;31:49-52.

18. Zargham-Boroujeni A, Elsagh A, Mohammadizadeh M. The Effects of Massage and Breastfeeding on Response to Venipuncture Pain among Hospitalized Neonates. Iran J Nurs Midwifery Res. 2017;22(4):308-12.

19. Desai SA, Nanavati RN, Jasani BB, Kabra N. Comparison of Neonatal Pain, Agitation, and Sedation Scale with Premature Infant Pain Profile for the Assessment of Acute Prolonged Pain in Neonates on Assisted Ventilation: A Prospective Observational Study. Indian J Palliat Care. 2017;23(3):287-92.

20. Alinejad-Naine M. Neonatal positioning during care in neonatal intensive care unit. Cardiovasc Nurs J [Internet]. 2014;3(1). Available from: http://journal.icns.org.ir/article-1-197-en.html

21. Oishi Y, Ohta H, Hirose T, Nakaya S, Tsuchiya K, Nakagawa M, et al. Combined effects of body position and sleep status on the cardiorespiratory stability of near-term infants. Sci Rep. 2018 Jun;8(1):8845.

22. Morlacchi L, Roggero P, Giannì ML, Bracco B, Porri D, Battiato E, et al. Protein use and weightgain quality in very-low-birth-weight preterm infants fed human milk or formula. Am J Clin Nutr. 2018;107(2):195-200. 